\title{
Chemical Control of Tomato Early Blight Disease
}

\author{
A.M.A. Ashour*; Tomader G. Abdel Rahman**; \\ H.M.A. Badawy ${ }^{* * *}$ and Nsreen D. Dib \\ * Plant Pathol. Dept., Fac. Agric., Cairo Univ. \\ ** Plant Pathol. Res. Inst., ARC, Giza, Egypt. \\ *** Economic Entomol. \& Pest. Dept., Fac. Agric., Cairo Univ. \\ **** Ministry of Higher Education, Syrian Arab Republic.
}

\begin{abstract}
A Iternaria solani (Ellis and Martin) Jones and Grout, the causal of tomato early blight, attacks all tomato hybrids and varieties, either in open field or in greenhouse, causing a serious damage that led to decrease in tomato yield. The fungus A. solani was isolated from tomato leaves and fruits, showing typical symptoms of early blight, collected from different locations distributed in six Egyptian Governorates. Pathological studies cleared that $A$. solani isolate taken from Menufiya was the most aggressive one; meanwhile, Ismailiya isolate was the lowest one in this concern. Disease control experiments revealed that all the tested fungicides inhibited, to different degrees, the in vitro growth of $A$. solani and decreased early blight severity under greenhouse conditions. The contact fungicides were more effective than the systematic ones, in controlling tomato early blight. Moreover, mancozeb $64 \%+$ metalaxyl $4 \%$ and copper hydroxide were the most effective ones, followed by systematic fungicides shirlan and dolphin Alfa.
\end{abstract}

Keywords: Alternaria solani, early blight, fungicides and tomato.

Tomato (Lycopersicon esculentum Mill), belongs to the family Solanaceae, is one of the most remunerable and widely grown vegetables in the world. It is grown for its edible fruits, which can be consumed either fresh or in processed form and is a very good source of vitamins (A, B and C) and minerals. The total area cultivated by tomato in Egypt during 2009 reached 101173,614 feddan with the productivity of 18, 09 tones/feddan (Anonymous, 2010). Under Egyptian conditions, tomato plants are vulnerable to the infection by different causal pathogens, i.e. fungi, bacteria and viruses (Abada et al., 2008), in addition to physiological disorders and nematode infections. However, fungal diseases, especially early blight caused by Alternaria solani (Ellis and Martin) Jones and Grout, is the most threatening one which causes great reduction in the quantity and quality of fruit yield reach up to 50\% (Reda et al., 1985; El-Abyad et al., 1993 and Abada et al., 2008).

Fungicide treatments are the most effective way to control early blight to a nondamaging level. Batista Tolentino et al. (2011) tested the efficacy of four different fungicides, i.e. azoxystrobin ( $8 \mathrm{~g} / 100 \mathrm{l})$, difenoconazole $(50 \mathrm{ml} / 100 \mathrm{l})$, metiram + pyraclostrobin $(200 \mathrm{~g} / 100 \mathrm{l})$ and tebuconazole $(100 \mathrm{ml} / 100 \mathrm{l})$, using two applications methods, i.e. conventional spraying and dripping, for controlling early blight on tomato. The tested fungicides caused decrements reached $27 \%$ in the disease 
severity in comparison with the check treatments. Also no significant differences were noted regarding the application method. Issiakhem and Boznad (2010) tested the efficacy of difenoconazole and chlorothalonil on controlling the in vitro conidial germination and mycelial growth of Alternaria alternata and A. solani. They found that difenoconazole was more effective than chlorothalonil against either mycelial growth or conidial germination. Moreover, A. solani showed more sensitivity than A. alternata to the tested fungicides. Ganishan and Chethana (2009) tested the efficacy of pyraclostrobin $25 \% \mathrm{EC}$ at 50,75 and $100 \mathrm{~g} / \mathrm{ha}$, against tomato early blight (cultivar NS2535) for two growing seasons. Also, commonly used chemicals, i.e. captan and mancozeb, as well as check (fungicide-free) plants were used for comparison. They found that pyraclostrobin at all tested concentrations significantly reduced the disease severity and increased the yield as compared to captan, mancozeb and check plants. In the first season, pyraclostrobin treated plots recorded a PDI (Percentage Disease Index) ranging from 10 to 15.5 and yield of 29.8 to 33.1 tons/ha as compared to a PDI of 30 and yield of 8.925 tons/ha in check treatment. In the second season, pyraclostrobin treated plots recorded a PDI ranging from 22.25 to 26.25 and a yield of 19.8 to 22.8 tons/ha as compared to a PDI of 35.25 and yield of 17.725 tons/ha in check treatment. Pyraclostrobin at 100, 200 and $400 \mathrm{~g}$ a.i./ha did not cause any phytotoxicity symptoms in terms of chlorosis, necrosis, wilting, scorching, hyponasty and epinasty. Arreaza and Hernandez (2001) tested the efficacy of azoxystrobin at 25, 50, 100 and $200 \mathrm{~g}$ a.i./ha in controlling tomato early blight caused by A. solani. Azoxystrobin was compared with mancozeb (1600 g a.i./ha), mancozeb + cimoxanilo $(960+120 \mathrm{~g}$ a.i./ha), mancozeb + metalaxyl $(1160+200 \mathrm{~g}$ a.i./ha) and with the untreated (check) plants. They reported that azoxystrobin at 100 and $200 \mathrm{~g}$ a.i./ha decreased the disease incidence to 3 and 5\% on the leaves, as well as to 2.5 and $3 \%$ on the fruits, respectively, seven weeks after transplanting, whereas mancozeb at 100 and 200 a.i./ha recorded disease incidence reached 32 and $63 \%$ on the leaves and between 30 to $57 \%$ on the fruits, respectively. Azoxystrobin at 100 and $200 \mathrm{~g}$ a.i./ha gave the highest tomato fruits yield (28.6 and 28.5 ton/ha, respectively), meanwhile mancozeb averaged 14 ton/ha.

Consequently, the objective of this research was designed to isolate and identify the causal organism of tomato early blight disease and determine its aggressiveness. Also, the efficacy of tested fungicides and their inhibitory effects, either on the causal fungus or on the disease severity, were studied under laboratory and greenhouse conditions.

\section{Materials and Methods}

1- The causal fungus:

a. Isolation, purification and identification:

Leaves and fruits of tomato plants, showing typical symptoms of early blight, were collected from different locations in six governorates, i.e. Behera, Ismailiya, Menufiya, Kafer El-Shaykh, Qalyubiya and Giza, during 2010/2011 growing seasons. Diseased samples were washed under tab water, cut into small pieces, surface sterilized by soaking in sodium hydrochloride $(0.2 \%)$ for $2-3$ minutes, followed by washing in three changes of sterilized water then dried between folds of 
sterilized filter papers. Sterilized plant fragments were aseptically transferred into Petri dishes (9-cm-diam.), each containing $20 \mathrm{ml}$ of potato dextrose agar (PDA) medium, and incubated at $25 \pm 1^{\circ} \mathrm{C}$. Plenty of conidiophores were easily recognized within 5-7 days, when conidia were easily picked off, under a dissecting microscope, using sterile needle and carefully placed into new PDA plates. Pure cultures were maintained on PDA slants for further studies. Purified fungal isolates were identified microscopically in Mycol. and Plant Dis. Survey Res. Dept., Plant Pathol. Res. Inst., ARC, according to the morphological characteristics, i.e. average length and width of conidia, pick length and the ratio of the pick length to conidial length, as described by Subramanian (1970) and Barnett and Hunter (1972).

\section{b. Inoculum preparation:}

Disks (5-mm-diam.) of tested fungal isolates, grown on PDA plates at $25 \pm 1^{\circ} \mathrm{C}$ for 7 days, were transferred into Petri dishes (9-cm-diam.), each containing $20 \mathrm{ml}$ of water agar plus $\mathrm{CaCo}_{3}$ and incubated in the dark at $18^{\circ} \mathrm{C}$ for $18-24 \mathrm{hr}$, then spores were harvest in sterilized distilled water and the concentration was adjusted to $5 \times 10^{4}$ conidia/ml (Shahin and Shepard, 1979).

\section{Pathogenicity of fungal isolates:}

\section{a. Laboratory experiment:}

Apparently healthy young leaflets of greenhouse-grown tomato plants (cv. Kallas) were detached, thoroughly washed with sterilized water and left between folds of sterilized filter papers for excess of water to dry, then placed into elevated plastic boxes fitted in moist chambers that was clear plastic tub $(10 \times 10 \times 4.5 \mathrm{~cm})$ with a lid that accommodated two leaflets from one plant (Gomaa, 2001). A volume of $15 \mathrm{ml}$ of sterilized water was added to each chamber, to provide a water source for the leaflets and to maintain high R.H. inside the chamber. Leaflets were laid down on the screen such that the pedicels were inserted into the water. Using a micropipette, $50 \mu \mathrm{l}$ droplet of tested spore suspension $\left(5 \times 10^{4}\right.$ conidia $\left./ \mathrm{ml}\right)$ was deposited on the upper surface of each leaflet. Three plastic boxes were used as replicates for each tested isolate. A set of leaflets were inoculated by sterilized water only and kept as control (check). All boxes were incubated at room temperature $\left(25 \pm 3^{\circ} \mathrm{C}\right)$ for 7 days then disease severity $(\%)$ was calculated.

\section{b. Greenhouse experiment:}

Tomato seeds (cv. Super Strain B), obtained from Vegetable Res. Dept., Hort. Res. Inst., A.R.C., were sown in ordinary cultivation trays filled with peat mossvermiculate $(1: 1 \mathrm{w} / \mathrm{w})$ for 30 days under greenhouse condition. Growing seedling were transplanted in pots (20-cm-diam.) filled with sterilized sandy-clay soil $(1: 1 \mathrm{w} / \mathrm{w})$ at the rate of 3 seedlings/pot. Growing plants (4-weeks-old) were sprayed, using a fine atomizer, with the tested spore suspension $\left(5 \times 10^{4}\right.$ conidia/ml $)$, then incubated under greenhouse conditions $\left(25 \pm 5^{\circ} \mathrm{C}\right.$ and $75-90 \%$ R.H.). Tomato plants sprayed with water only were kept as check. Three replicates were used for each isolate. Disease severity percentage was determined 10, 20 and 30 days after inoculation. 


\section{c. Disease assessment:}

The following numerical rates were suggested to facilitate visual determination and to give a satisfactory comparison:

$0=$ no symptoms appear on the leaflet.

$1=$ less than $1 / 4$ of the leaflet area is covered by the symptoms.

$2=$ about $1 / 4$ to $1 / 2$ of the leaflet area is covered by the symptoms.

$3=$ about $1 / 2$ to $3 / 4$ of the leaflet area is covered by the symptoms.

$4=$ more than $3 / 4$ of the leaflet area is covered by the symptoms.

Symptoms were converted to disease index according to the equation suggested by Townsend and Heuberger (1943), as follows:

Disease severity $(\%)=\frac{\Sigma(\mathrm{n} \times \mathrm{r})}{\text { NR }}$

Whereas: (n) is the number of tested plant materials in each numerical rate (r), and (N) is the total number of plant materials multiplied by the highest numerical rate $(\mathrm{R})$.

3. Evaluation of fungicides against the causal fungus:

a. In vitro evaluation:

The inhibitory effect of eight fungicides (Table 1) was determined on base of their active ingredients using five concentrations, i.e. 200, 250, 500, 750 and 1000 ppm, against the linear growth of the most and less virulent fungal isolates, taken from Menufiya and Ismailiya Governorates. Different rates of the tested fungicides were individually added to conical flasks containing sterilized PDA medium before its solidification to obtain the proposed concentrations and rotated gently to ensure equal distribution of fungicide, then disbanded in sterilized Petri-plates (9-cm-diam.).

Petri dishes, each contained $10 \mathrm{ml}$ of PDA medium, were individually inoculated in the centre with 5-mm-disc taken from 10- day-old culture of the tested fungal isolates. Three replicated plates were used for each concentration. A set of fungicide-free PDA plates were inoculated by the tested fungal isolates and served as check. All tested plates were incubated at $25 \pm 1^{\circ} \mathrm{C}$ for 10 days. The reduction percentages in fungal linear growth were calculated using the formula of Chapagain et al. (2007) as follows:

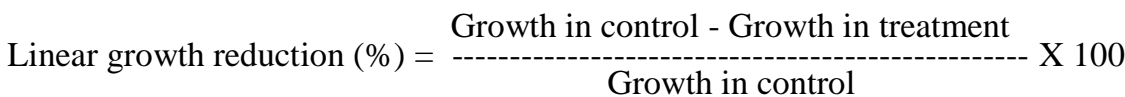

Medium effective concentration $\left(\mathrm{EC}_{50}\right)$ was also calculated for each tested fungicide using the Lpd Line Programme (Version 1.0) (Anonymous, 2012).

\section{b. In vivo evaluation:}

This experiment was conducted in the greenhouse of Vegetable Dis. Res. Dept., Plant Pathol. Inst., ARC. Three tomato seedlings (30-day-old) of hybrid (Shiva F1), the highly susceptible to early blight disease, were transplanted in each pot $(20-\mathrm{cm}-$ diam.) filled with sandy-clay soil $(1: 1 \mathrm{w} / \mathrm{w})$. Growing seedlings were divided into two groups as follows: 
Table 1. Trade names, common names, chemical names, rates of application and chemical group of the tested fungicides

\begin{tabular}{|c|c|c|c|c|}
\hline Trade name & Common name & Chemical name & Chemical group & $\begin{array}{c}\text { Rat of } \\
\text { application } \\
/ 100 \text { l water }\end{array}$ \\
\hline $\begin{array}{l}\text { Oxy plus } \\
28.5 \% \mathrm{WP}\end{array}$ & $\begin{array}{l}\text { Copper } \\
\text { hydroxide }\end{array}$ & Copper hydroxide & $\begin{array}{l}\text { Inorganic } \\
\text { fungicides } \\
\text { (Copper } \\
\text { compounds) } \\
\end{array}$ & $250 \mathrm{~g}$ \\
\hline $\begin{array}{l}\text { Ridomil Gold } \\
\text { MZ 68\% WP }\end{array}$ & $\begin{array}{l}\text { Mancozeb 64\% } \\
+ \text { Metalaxyl 4\% }\end{array}$ & $\begin{array}{l}\text { Manganese and zinc } \\
\text { ethylenbisdithiocarbamate and N-(2,6- } \\
\text { dimethylphenyl) N-(methoxyacytel)-DL- } \\
\text { alanine methyl ester }\end{array}$ & $\begin{array}{l}\text { Carbamate } \\
\text { (Dithincarba- } \\
\text { mate)+Acylala- } \\
\text { nine }\end{array}$ & $200 \mathrm{~g}$ \\
\hline $\begin{array}{l}\text { Shirlan } \\
50 \% \mathrm{SC}\end{array}$ & Fluazinam & $\begin{array}{l}\text { 3-chloro-N-[3-chloro-2,6-dinitro-4- } \\
\text { (trifluoromethyl)phenyl]-5- } \\
\text { (trifluoromethyl)-2-pyridinamine } \\
\end{array}$ & $\begin{array}{l}2,6 \\
\text { dinitroaniline }\end{array}$ & $50 \mathrm{ml}$ \\
\hline $\begin{array}{l}\text { Dolphin Alfa } \\
25 \% \text { EC }\end{array}$ & Difenoconazole & $\begin{array}{l}\text { Cis, trans-3-chloro-4- [4-methyl-2-(14- } \\
\text { 1,2,4-triazol-1-4lmethyl)= 1,3-dioxolan- } \\
\text { 2-yllphenyl -4-chlorophenyl ether }\end{array}$ & $\begin{array}{l}\text { Triazole } \\
\text { compound }\end{array}$ & $50 \mathrm{ml}$ \\
\hline $\begin{array}{l}\text { Ranman } \\
40 \% \text { SC }\end{array}$ & Cyanoimidazole & $\begin{array}{l}\text { 4-Chloro-2-cyano- } N, N \text {-dimethyl-5-p- } \\
\text { tolylimidazole-1-sulfonamide(IUPAC); } \\
\text { 4-chloro-2-cyano- } N, N \text {-dimethyl-5-(4- } \\
\text { methylphenyl)- } H \text {-imidazole-1- } \\
\text { sulfonamide }\end{array}$ & Cyanoimidazole & $30 \mathrm{ml}$ \\
\hline $\begin{array}{l}\text { Revus } 25 \% \\
\mathrm{SC}\end{array}$ & Mndipropamid & $\begin{array}{l}\text { 2-(4-chlorophenyl)-N-[2-(3-methoxy-4- } \\
\text { prop-2-ynyloxyphenyl)-ethyl]-2 - } \\
\text { prop-2-ynyloxy acetamide }\end{array}$ & Mandelamide & $50 \mathrm{ml}$ \\
\hline Flint $50 \% \mathrm{WG}$ & Trifloxystrobin & $\begin{array}{l}\text { Methyl }(\alpha E)-\alpha \text {-(methoxyimino)-2-[[[(E) } \\
-1-3 \text {-(trifluoromrthyl)phenyl] ethylidene }] \\
\text { amino]oxy]methyl]benzenacetate }\end{array}$ & $\begin{array}{l}\text { Strbilurin } \\
\text { compounds }\end{array}$ & $20 \mathrm{~g}$ \\
\hline $\begin{array}{l}\text { Amisulbrom } \\
20 \% \text { SC }\end{array}$ & Sulfonamide & $\begin{array}{l}\text { 3-(3-bromo-6-fluoro-2-methylindol-1- } \\
\text { ylsulfonyl)- } N, N \text {-dimethyl-1H-1,2,4- } \\
\text { triazole-1-sulfonamide }\end{array}$ & unclassified & $50 \mathrm{ml}$ \\
\hline
\end{tabular}

1. In the first group, growing tomato plants (15 days after transplanting) were sprayed with tested fungicides, and then sprayed after three days with the spore suspension $\left(5 \times 10^{3}\right.$ conidia/ml $)$ of Menufiya isolate.

2. In the second group, growing tomato plants (15 days after transplanting) were sprayed with spore suspension $\left(5 \times 10^{3}\right.$ conidia/ml) of Menufiya isolate, then sprayed after three days with the tested fungicides.

Treated plants were incubated under controlled greenhouse conditions $\left(25 \pm 5^{\circ} \mathrm{C}\right.$ and 75-90\% R.H.) and the disease intensity was calculated 10, 20 and 30 days after fungicides application. Also, three replicates of tomato plants inoculated with the tested pathogen and sprayed with water only, were served as check. The efficacy of each treatment was calculated using the following equation (Derbalah et al., 2011):

Fungicide efficacy $(\%)=\frac{\text { DSC }- \text { DST }}{-------X 100}$

Whereas: DSC: Disease severity in the inoculated plants (check).

DST: Disease severity in the inoculated and fungicidal sprayed plants. 
Statistical analysis:

Recorded data were statistically analyzed, whenever needed, using ANOVA of ASSISTAT statistical data analysis software. Duncan's multiple range tests was used to determine the most significant treatment (Duncan, 1955).

\section{R e s u l t s}

1. Isolation and identification of the associated fungi:

During the experimental course of isolation from the collected diseased tomato samples, 13 fungal isolates were purified and identified according to their microscopical and morphological characters. Presented data in Table (2) reveal that the isolated fungi were found to belonging to two species of the genus Alternaria, i.e. 6 isolates of A. alternate and 7 isolates of A. solani. Similar results were also reported by many investigators (Reda et al., 1985; El-Abyad et al., 1993 and Abada et al., 2008).

Table 2. Full isolation of the causal fungi from different Egyptian Governorates

\begin{tabular}{|l|c|c|c|}
\hline \multirow{2}{*}{ Governorate } & \multicolumn{2}{|c|}{ Alternaria spp. } & \multirow{2}{*}{ Total } \\
\cline { 2 - 3 } & A. solani & A. alternata & \\
\hline Behera & 1 & 1 & 2 \\
\hline Giza & 1 & 0 & 1 \\
\hline Ismailiya & 1 & 0 & 1 \\
\hline Kafer El-Shaykh & 2 & 1 & 3 \\
\hline Menufiya & 1 & 3 & 4 \\
\hline Qalyubiya & 1 & 1 & 2 \\
\hline Total & 7 & 6 & 13 \\
\hline
\end{tabular}

\section{Pathogenicity of fungal isolates:}

The pathogenic potentiality of the seven A. solani isolates, the causal of tomato early blight disease, was in vivo determined under either laboratory or greenhouse conditions.

\section{a. Laboratory experiments:}

Tested A. solani isolates were examined for their pathogenic ability using tomato (cv. Kallas) detached leaf technique according to Gomaa (2001). Data presented in Table (3) show that Menufiya isolate was the most virulent one, when possessed disease severity reached $66.7 \%$, followed by isolate (b) from Kafer El-Shaykh (being 41.7\%). Meanwhile, Giza and Qalyubiya isolates showed moderately $(29.3 \%)$ virulence on tested tomato leaves. Also, Kafer El-Shaykh (a) and Behera isolates recorded $25.0 \%$ disease severity. On the other hand, Ismailiya isolate recorded the lowest $(16.7 \%)$ disease severity on tomato leaves.

b. Greenhouse experiment:

Pathogenicity of tested A. solani isolates was determined on 4-week-old tomato plants (cv. Super Strain B) under greenhouse conditions. Table (4) show that after 10 days of inoculation, Menufiya isolate was the most virulent one (reached $43.0 \%$ disease severity), followed by Kafer El-Shaykh (b) (being 40.3\%), meanwhile 
Table 3. Disease severity (\%) of seven A. solani isolates on tomato (cv. Kallas) under laboratory conditions

\begin{tabular}{|l|c|}
\hline \multicolumn{1}{|c|}{ Tested isolate } & Disease severity $(\%)^{*}$ \\
\hline Behera & $25.0 \mathrm{c} * *$ \\
\hline Giza & $29.3 \mathrm{c}$ \\
\hline Ismailiya & $16.7 \mathrm{~d}$ \\
\hline Kafer El-Shaykh (a) & $25.0 \mathrm{c}$ \\
\hline Kafer El-Shaykh (b) & $41.7 \mathrm{~b}$ \\
\hline Menufiya & $66.7 \mathrm{a}$ \\
\hline Qalyubiya & $29.3 \mathrm{c}$ \\
\hline
\end{tabular}

* Results were recorded 7 days after inoculation.

** Each figure represents the mean of 3 replicates.

- Figures within the same column with the same letter are not significantly different $(\mathrm{P}<0.05)$.

Table 4. Disease severity of seven $A$. solani isolates on tomato (cv. Super Strain B) under greenhouse conditions

\begin{tabular}{|c|c|c|c|c|}
\hline \multirow{2}{*}{ Tested isolate } & \multicolumn{3}{|c|}{ Disease severity (\%) after (days)* } & \multirow{2}{*}{ Mean } \\
\hline & 10 & 20 & 30 & \\
\hline Behera & $19.4 \mathrm{c}$ & $21.1 \mathrm{c}$ & $22.2 \mathrm{e}$ & 20.9 \\
\hline Giza & $18.1 \mathrm{c}$ & $21.2 \mathrm{c}$ & $23.3 \mathrm{e}$ & 20.87 \\
\hline Ismailiya & $11.1 \mathrm{~d}$ & $13.1 \mathrm{~d}$ & $17.8 \mathrm{f}$ & 14 \\
\hline Kafer El-Shaykh (a) & $20.8 \mathrm{c}$ & $23.6 \mathrm{c}$ & $27.9 \mathrm{~d}$ & 24.1 \\
\hline Kafer El-Shaykh (b) & $40.3 \mathrm{a}$ & $43.2 \mathrm{a}$ & $47.6 \mathrm{~b}$ & 43.7 \\
\hline Menufiya & $43.0 \mathrm{a}$ & $46.6 \mathrm{a}$ & $51.4 \mathrm{a}$ & 47 \\
\hline Qalyubiya & $33.3 \mathrm{~b}$ & $35.4 \mathrm{~b}$ & $38.6 \mathrm{c}$ & 35.77 \\
\hline Control ** & 00.0 & 00.0 & 00.0 & 00.0 \\
\hline
\end{tabular}

* Data were recorded 10, 20 and 30 days after inoculation of tomato plants with tested isolates.

** Tomato plants sprayed with water only were served as control.

- Figures with in the same column having the same letter are not significantly different $(\mathrm{P}<0.05)$.

Qalyubiya isolate recorded moderate effect (being 33.3\% virulence). On the other hand, Behera, Giza, and Ismailiya isolates were the lowest in this concern, they recorded 19.4, 18.1 and $11.1 \%$, respectively. The same trend of results was found 20 and 30 days after inoculation.

3. Evaluation of fungicides against the causal fungus:

a. In vitro evaluation:

Results in Tables (5 and 6) show the toxicity of the tested fungicides against most and less aggressive $A$. solani isolates. The candidate fungicides were arranged according to $\mathrm{EC}_{50}$ values (The effective concentrations of fungicides that inhibited mycelial growth by $50 \%$ ) for the most and less aggressive A. solani isolates in the following ascending order; shirlan (0 and $0.01 \mathrm{ppm})$, Oxy plus (11,59 and 12.17 ppm), Ridomil Gold (16.39 and $0.02 \mathrm{ppm}$ ), Amisulbrom (53.0 and $2.35 \mathrm{ppm}$ ), Flint (205,2 and 4.15 ppm), Revus (895.95 and 394.38 ppm) and Ranman (45269.26 and $530.27 \mathrm{ppm}$ ). Based on $\mathrm{EC}_{90}$ level, the same trend of efficiency was obtained (Tables 5 and 6). Obtained results confirmed that shirlan was the most toxic followed by 
Table 5. Toxicity values of tested fungicides against the most aggressive A. solani isolate

\begin{tabular}{|l|c|c|c|c|}
\hline \multicolumn{1}{|c|}{ Fungicide } & $\begin{array}{c}\mathrm{EC}_{25} \\
(\mathrm{ppm})\end{array}$ & $\begin{array}{c}\mathrm{EC}_{50} \\
(\mathrm{ppm})\end{array}$ & $\begin{array}{c}\mathrm{EC}_{90} \\
(\mathrm{ppm})\end{array}$ & \multicolumn{1}{c|}{ Slope } \\
\hline Revus 25\% SC & 328.99 & 895.9 & 6011.846 & $1.5502 \pm 0.2297$ \\
\hline Flint 50\% WG & 33.77 & 205.2 & 6330.835 & $0.8607 \pm 0.2145$ \\
\hline Shirlan 50\% SC & 0.0 & 0.0 & $1.31 \mathrm{E}+16$ & $0.0482 \pm 0.2246$ \\
\hline Ranman 40\% SC & 491.91 & 45269.26 & $2.44 \mathrm{E}+08$ & $0.3434 \pm 0.2287$ \\
\hline Dolphin Alfa 25\% EC & 0.0 & 0.0 & $8.89 \mathrm{E}+10$ & $0.1285 \pm 0.2020$ \\
\hline Ridomil Gold MZ 68\% & 0.041 & 16.39 & 1389964 & $0.2601 \pm 0.0888$ \\
\hline Oxy plus 28.5\% WP & 8.48 & 11.59 & 20.96 & $4.9794 \pm 0.9675$ \\
\hline Amisulbrom 20\% SC & 7.84 & 53.00 & 1998.62 & $0.813 \pm 0.4407$ \\
\hline
\end{tabular}

Table 6. Toxicity values of tested fungicides against the less aggressive A. solani isolate

\begin{tabular}{|l|c|c|l|c|}
\hline \multicolumn{1}{|c|}{ Fungicide } & $\begin{array}{c}\mathrm{EC}_{25} \\
(\mathrm{ppm})\end{array}$ & $\begin{array}{c}\mathrm{EC}_{50} \\
(\mathrm{ppm})\end{array}$ & $\begin{array}{c}\mathrm{EC}_{90} \\
(\mathrm{ppm})\end{array}$ & Slope \\
\hline Revus 25\% SC & 4.14 & 394.38 & 68102.63 & $0.6078 \pm 0.2103$ \\
\hline Flint 50\% WG & 0.054 & 4.15 & 2269850 & $0.3408 \pm 0.2728$ \\
\hline Shirlan 50\% SC & 0.0 & 0.01 & 15747.44 & $0.1761 \pm 0.0826$ \\
\hline Ranman 40\% SC & 41.18 & 530.27 & 258239.9 & $0.6078 \pm 0.2103$ \\
\hline Dolphin Alfa 25\% EC & 0.0 & 0.0 & 456.62 & $0.0721 \pm 0.1921$ \\
\hline Ridomil Gold MZ 68\% & 0.0001 & 0.02 & 406.45 & $0.2974 \pm 0.0836$ \\
\hline Oxy plus 28.5 \% WP & 3.34 & 12.17 & 141.67 & $1.2023 \pm 0.7820$ \\
\hline Amisulbrom 20\% SC & 0.036 & 2.35 & 6512.89 & $0.3723 \pm 0.5705$ \\
\hline
\end{tabular}

Ridomil Gold, Oxy plus and Amisulbrom. Flint, Revus and Ranman showed a moderate activity toward $A$. solani isolates. Concerning the slope values of the toxicity lines, Oxy plus 4.97 and 1.20 (for the most and less aggressive A. solani isolates, respectively) showed the steepest toxicity line. The other toxicity lines had approximately equal slope values and ranged between $0.04-1.55$ and $0.20-0.60$ (for Menufiya and Ismailiya isolates, respectively) which indicate that the differences in toxicity of these compounds are due to its intrinsic toxicity.

b. In vivo evaluation:

This experiment was conducted under greenhouse conditions to evaluate the efficiency of the aforementioned above mentioned fungicides for in vivo capability to control tomato early blight disease. Obtained data presented in Table (7) indicate that all the tested fungicides were effective in reducing the disease severity of tomato early blight disease when compared with the control treatment. Disease severity of tomato early blight reached $23.79 \%$ in control treatment, and ranged between $4.69 \%$ to $15.30 \%$ and $2.19 \%$ to $12.06 \%$ when the tested fungicides applied 3 days after and before inoculation, respectively. Moreover, data show that the Ridomil Gold MZ and Oxy plus were the most effective ones (77.21, 75.19 and 88.06, 85.58 after and before inoculation, respectively, followed by shirlan, 
Table 7. Effect of different fungicides on tomato early blight disease under greenhouse conditions

\begin{tabular}{|c|c|c|c|c|c|c|c|c|}
\hline \multirow{3}{*}{ Fungicide } & \multicolumn{8}{|c|}{ Disease severity $(\%) *$} \\
\hline & \multicolumn{4}{|c|}{ Application after inoculation } & \multicolumn{4}{|c|}{ Application before inoculation } \\
\hline & 10 & $\mathrm{E}(\%)$ & 20 & $\mathrm{E}(\%)$ & 10 & $\mathrm{E}(\%)$ & 20 & $\mathrm{E}(\%)$ \\
\hline Revus $25 \% \mathrm{SC}$ & $15.78 b$ & 27.18 & $17.08 \mathrm{~b}$ & 34.98 & $12.06 \mathrm{~b}$ & 44.34 & $13.36 b$ & 49.14 \\
\hline Flint 50\% WG & $10.92 \mathrm{~d}$ & 49.60 & $12.38 d$ & 52.87 & $8.03 \mathrm{~d}$ & 62.94 & $9.33 \mathrm{c}$ & 64.48 \\
\hline Shirlan 50\% SC & $6.80 \mathrm{e}$ & 68.62 & $8.10 \mathrm{e}$ & 69.17 & $4.65 f$ & 78.54 & $5.95 \mathrm{f}$ & 78.72 \\
\hline Ranman $40 \% \mathrm{SC}$ & $15.30 \mathrm{~b}$ & 29 & $16.76 \mathrm{~b}$ & 36.20 & $11.47 \mathrm{~b}$ & 47.07 & $12.77 \mathrm{~b}$ & 51.39 \\
\hline Dolphin Alfa $25 \%$ EC & $7.14 \mathrm{e}$ & 67 & $8.40 \mathrm{e}$ & 68 & $6.83 \mathrm{e}$ & 68 & $8.13 \mathrm{e}$ & 69.05 \\
\hline Ridomil Gold MZ 68\% & $4.69 f$ & 76.05 & $6.15 \mathrm{f}$ & 76.58 & $2.19 f$ & 89.89 & $3.49 \mathrm{~g}$ & 86.71 \\
\hline Oxy plus $28.5 \% \mathrm{WP}$ & $5.17 f$ & 76.14 & $6.63 f$ & 74.76 & $2.78 \mathrm{f}$ & 87.17 & $4.08 \mathrm{~g}$ & 84.47 \\
\hline Amisulbrom $20 \% \mathrm{SC}$ & $12.36 \mathrm{c}$ & 42.96 & $13.74 \mathrm{c}$ & 47.69 & $10.32 \mathrm{c}$ & 52.37 & $11.57 \mathrm{~d}$ & 55.95 \\
\hline Control** & $21.67 \mathrm{a}$ & 00.00 & $26.27 \mathrm{a}$ & 00.00 & $21.67 \mathrm{a}$ & 00.00 & $26.27 \mathrm{a}$ & 00.00 \\
\hline \multicolumn{9}{|c|}{$\begin{array}{l}\text { Tested fungicides were applied three days before or after inoculation with the tested A. solani } \\
\text { spore suspension }\left(5 \times 10^{4} \text { conidia/ ml). Data were recorded } 10 \text { and } 20 \text { days after application of }\right. \\
\text { the recommended dose of each tested fungicides. }\end{array}$} \\
\hline \multicolumn{9}{|c|}{ ** Tomato plants were sprayed by water only and served as control. } \\
\hline \multicolumn{9}{|c|}{$\begin{array}{l}\text { - } \quad \text { Values within the same column with the same letter are not significantly different }(\mathrm{P}<0.05) \text {. } \\
\text { - } \quad \text { Each figure represents the mean of } 3 \text { replicates. }\end{array}$} \\
\hline
\end{tabular}

dolphin Alfa and Flint being, 68.68, 67.33 and 51.02\% 3 days after inoculation and $78.47,68.55$ and $63.51 \% 3$ days before inoculation, respectively. On the other hand, the lowest effectiveness (\%) was recorded in case of Amisulbrom, Ranman and Revus, being 42.96, 29.39 and 27.18\% 3 days after inoculation, and 52.37, 47.07 and $44.34 \% 3$ days before inoculation. Generally, all fungicides were most effective when applied 3 days before inoculation, and contact fungicides were more effective in controlling tomato early blight disease than the systematic fungicides.

\section{D i s c us s i o n}

Tomato early blight infecting Solanaceae is caused by two fungal species from Alternaria genus (Kapsa and Osowski, 2007). These two species are A. solani casual agent of early blight and $A$. alternata causal agent of brown leaf spots. Both species differ in some morphological features such as mycelium colour and mycelium growth rate on the media, spore structures and temperature requirements (Leiminger et al., 2010). In this regard, the Microscopical examination revealed that $75 \%$ of spores were A. alternata and only $18 \%$ A. solani (Tymon and Johnson, 2011). Osowski (2011) found that the intensity of spore occurrence of A. solani was related to a higher amount of rainfall, followed by rainless periods, while a lower amount of rain with uneven distribution favoured the fungus A. alternata.

It is clear that the different $A$. solani isolates were differed in their pathogenicity to the tomato cultivar Super Strain B. Results show that Menufiya isolate was the most virulent one; meanwhile Ismailiya isolate was the lowest in this concern. The variation in virulence of the tested isolates was the principle causality of disease severity variation on cv. Super Strain B. There are many studies regarding the 
variation of the different A. solani isolates. Lourinco (2008); Rao et al. (2008) and Weber and Halterman (2012) reported many variations in morphology in vivo and in vitro, physiology, genetic makeup and pathogenicity among $A$. solani isolates. Van der Waals et al. (2004) detected a high genetic diversity among A. solani isolates originating from different countries, i.e. USA, South Africa, Cuba, Brazil, Turkey, Greece, Canada, China and Russia, based on vegetative compatibility groups (VCG,) and molecular markers (isozymes, random amplified polymorphic DNA.

The effect of fungicides, i.e. Ridomil Gold MZ 68\%, Flint 50\% WG, Ranman $40 \%$ SC and Amisulbrom 20\% SC were evaluated in vitro for their inhibitory effect on the linear growth of Alternaria solani, the causal of tomato early blight. Also, they were evaluated under greenhouse and field conditions for their efficiency in managing the artificial inoculation with the causal of the disease.

Obtained data revealed that all the tested fungicides caused significant reduction in the linear growth of $A$. solani. This reduction was gradually increased by increasing its active ingredient concentrations. Dolphin Alfa and shirlan were the most efficient fungicide for inhibiting the linear growth of the tested fungus. On the other hand, Amisulbrom and Ranman followed by Revus were less effective in this concern. Moreover, application of these fungicides after and before inoculation with A. solani under greenhouse conditions, reduced disease severity in comparison with control treatment. The inhibitory effect of most of these fungicides to the growth of A. solani was reported by many researchers (Christ and Maczuga, 1989; Shtienberg et al., 1996; Holm et al., 2003; Kapsa, 2004; AL-Mughrabi, 2004 and Abdel-Sayed, 2006). Hawamdeh and Ahmed (2001) found that at $250 \mathrm{ppm}$ concentration the lowest growth $(2.02 \mathrm{~cm})$ was observed in the treatment of Dithian M-45.

The toxicity of the tested fungicides against most aggressive and less aggressive A. solani isolates showed that shirlan was the most toxic followed by Ridomil Gold, Oxy plus and Amisulbrom which showed a moderate activity toward A. solani isolates. Whereas, Flint, Revus and Ranman were less active as indicated by $\mathrm{EC}_{50}$ values. Two $A$. solani isolates were sensitive to these fungicides, having the $\mathrm{EC}_{50}$ values between 0-895.9 ppm and 0.01-530.27 ppm, respectively. Stepanovic et al. (2009) found that Iprodione, Difenoconazole and Prochloraz proved them to be the most effective as indicated by $\mathrm{EC}_{50}$ values. They added that all $A$. solani isolates were highly sensitive to these fungicides, having the $\mathrm{EC}_{50}$ values between 0.40-0.80 $\mathrm{mg} / \mathrm{l}, 0.09-0.33 \mathrm{mg} / \mathrm{l}$ and $0.03-0.11 \mathrm{mg} / \mathrm{l}$, respectively.

Greenhouse experiment indicated that all tested fungicides. Ridomil Gold MZ and Oxy plus were more effective against early blight disease followed by shirlan and dolphin Alfa under greenhouse conditions. Also, all fungicides were most effective when applied 3 days before inoculation, and contact fungicides were more effective in control of tomato early blight disease than the systematic fungicides. Similar results were reported by Horsfield et al. (2010) who found that Timing of fungicide application and product selection were significant factors in early blight control in both the greenhouse and field experiments. Applying fungicides before inoculation was more effective than applications after inoculation and this demonstrates that most of the fungicides evaluated have greater protective than 
curative activity. They concluded that Boscalid and Azoxystrobin were highly effective protective treatments in the field experiment when applied a day before inoculation. Difenoconazole provided the most consistent post-infection activity, with the lowest level of disease development in the treatments that were applied after inoculation. Bouwman and Rijkers (2004) found that the high preventative control of A. solani by Azoxystrobin, Chlorothalonil and Difenoconazole at the lowest rates was achieved when they applied at three days before inoculation. They added that Azoxystrobin at the two lowest rates was more effective. This activity could be due to causing collapse of the mycelium within the leaf. Also, Difenoconazole showed good effect at the two highest rates. Tofoli (2011) found that the systemic fungicides or high tenacity ones provided control of early blight disease until 12 days after application, while the Translaminar ones were effective until 9 days after application. The curative action, the systemic fungicides stand out when applied until 24 hours post inoculation.

Results of the present study showed that most of fungicides significantly controlled the early blight infection on tomato as compared to untreated control. Moreover, the timing of fungicide application and product selection were significant factors in early blight control.

\section{Refere n c e s}

Abada, K.A.; Mostafa, S.H. and Hillal, Mervat R. 2008. Effect of some chemical salts on suppressing the infection by early blight disease of tomato. Egypt. J. Appl. Sci., 23 (20): 47-58.

Abdel-Sayed, M.H.F. 2006. Pathological, physiological and molecular variations among isolates of Alternaria solani the causal of tomato early blight disease. Ph.D. Thesis, Fac. Agric., Cairo Univ. 181pp.

AL-Mughrabi, K.I. 2004. Sensitivity of Jordanian isolates of Alternaria solani to Mancothane. Phytopathol. Mediterr., 43: 14-19.

Anonymous, 2010. Yearbook of Statistics of Ministry of Agriculture. Agricultural Economical and Statistical Dept., Arab Republic of Egypt, Cairo. [In Arabic].

Anonymous, 2012. Lpd Line Programme (Version 1.0). On line internet http://www.ehabsoft.com/ldpline/DownloadForm.htm.

Arreaza, J.M. and Hernandez, M.M. 2001. Evaluation of Azoxystrobin on the early blight control (Alternaria solani) in tomatoes. Revista de la Facultad de Agronomia, 18 (2): 106-116.

Barnett, H.L. and Hunter, B.B. 1972. Illustrated Genera of imperfect Fungi. Burgin Pub. Co., Minnesota, USA. 241pp.

Batista Tolentino, J.B. jr.; Rezende, R.; Itako, A.T.; Lourenço de Freitas, P.S. and Frizzone, J.A. 2011. Drip fungigation in early blight control of tomato. Acta Sci. Agron., 33 (1): 9-14. (http://dx.doi.org/10.4025/actasciagron.v33i1.9515). 
Bouwman, J.J. and Rijkers, G. 2004. The control of Alternaria solani (early blight) with Azoxystrobin in potatoes. Pages: 179-188. In: PPO-Special Report No. 10. Westerdijk, C.E and Schepers, H.T. (eds.). Appl. Plant Res., AGV Res. Unit.

Chapagain, B.P.; Wiesman, Z. and Tsror Lahkim, L. 2007. In vitro study of the antifungal activity of saponin-rich extracts against prevalent phytopathogenic fungi. Industrial Crops and Products, 26: 109-115.

Christ, B.J and Maczuga, S.A. 1989. Effect of fungicides schedules and inoculums levels on early blight severity and yield of potato. Plant Dis, 73: 695- 698.

Derbalah, A.S.; El-Mahrouk, M.S. and El-Sayed, A.B. 2011. Efficacy and safety of some plant extracts against tomato early blight disease caused by Alternaria solani. Plant Pathol. J., 10 (3): 115-121.

Duncan, D.B. 1955. Multiple range and multiple F-test. Biometrics, 11 (1): 1-24.

El-Abyad, M.S.; El-Sayed, M.A.; El-Shanshoury, A.R. and El-Abbagh, S.M. 1993. Towards the biocontrol of fungal and bacterial diseases of tomato using antagonistic Streptomyces spp. Plant and Soil, 149 (2): 185-195.

Ganishan, G. and Chethana, B.B. 2009. Bioefficacy of Pyraclostrobin 25\% EC against early blight of tomato. World Appl. Sci. J., 7 (2): 227-229.

Gomaa, A.M.I. 2001. Pathological studies on early blight of tomato. M.Sc. Thesis., Fac. Agric., Cairo Univ.185pp.

Hawamdeh, A.S. and Ahmed, S. 2001. In vitro control of Alternaria solani, the Cause of early blight of tomato. J. Biol. of Sci., 1 (10): 949-950.

Holm, A.L.; Rivera, V.V.; Secor, G.A. and Gudmested, N.C. 2003. Temporal sensitivity of Alternaria solani to foliar fungicides, Am. J. Potato Res., 80: $33-40$

Horsfield, A.; Wicks, T.; Davies, K.; Wilson, D. and Scott Paton, S. 2010. Effect of fungicide use strategies on the control of early blight (Alternaria solani) and potato yield. Australasian Plant Pathology, 39: 368-375.

Issiakhem, F. and Boznad, Z. 2010. In vitro evaluation of Difenoconazole and Chlorothalonil on conidial germination and mycelial growth of Alternaria alternata and A. solani causal agent of early blight in Algeria. PPO-Special Report, 14: 297-302.

Kapsa, J. 2004. Early blight (Alternaria spp.) in potato crops in Poland and results of chemical protection. J. Plant Protect. Res., 44 (3): 231-328.

Kapsa, J. and Osowski, J. 2007. Evaluation of performance of Burked trap in identification of Alternaria species infecting potato crops. PPO-Special Report, 12: $183-188$.

Leiminger, J.; Bahnweg, G. and Hausladen, H. 2010. Population genetics consequences on early blight disease. $12^{\text {th }}$ Euro-Blight Workshop, Arras, France. 
Lourinco, V. jr. 2008. Genetics of rate limiting disease reaction to Alternaria solani in tomato. Ph.D. Thesis, Federal de Vicosa University, 140pp.

Osowski, J. 2011. The occurrence of Alternaria spores in vegetative season in 2008-2009. Progress in Plant Protection, 51 (2): 678-683.

Rao, E.S.; Munshi, A.D. and Rajkumar, P.S. 2008. Genetics of rate limiting disease reaction to Alternaria solani in Tomato. Euphytica, 159: 123-134.

Reda, F.; Mousa, O.M.; Sejiny, M.J. and Nawar, L.S. 1985. Responses of tomato cultivars to infection with Alternaria solani in relation to growth and chemical composition of their fruits. Egypt. J. Phytopathol., 17 (2): 83-93.

Shahin, E.A. and Shepard, J.F. 1979. An efficient technique for inducing profuse sporulation of Alternaria species. Phytopathology, 69: 618-620.

Shtienberg, D.; Blachinsky, D.; Ben-Hador, G. and Dinoor, A. 1996. Effects of growing season and fungicide type on the development of Alternaria solani and on potato yield. Plant Dis., 80: 994-998.

Stepanovic, M.; Vuksa, P.; Potocnik, I.; Milijasevic, S.; Rekanovic, E. and Todorovic, B. 2009. Integrated Management of Viral Sensitivity of Alternaria solani Isolates to Some Fungicides. Acta Hort., 80 (8): 377-380.

Subramanian, C.V. 1970. Hyphomycetes: An Account of Indian Species. Book Co., Inc. Madras, India. 930pp.

Tofoli, J.G. 2011. Fungicides and resistance inductors action in the control of late and early bight in potato crops. Ph.D. Thesis, Fac. Agric., Sao Paulo Univ. $176 \mathrm{pp}$.

Townsend, G.K. and Heuberger, J.W. 1943. Methods for estimating losses caused by diseases in fungicide experiments. Plant Dis. Reptr., 27: 340-343.

Tymon, L.S. and D. A. Johnson, D.A. 2011. Prevalence and aggressiveness of Alternaria solani and A. alternata on potato in the Columbia Basin of the Pacific Northwest. Phytopathology, 101: S180. [Abstract].

Van der Waals, J.E.; Korsten, L. and Slippers, B. 2004. Genetic diversity among Alternaria solani isolates from potatoes in South Africa. Plant Dis., 88: 959-964.

Weber, B. and Halterman, D.A. 2012. Analysis of genetic and pathogenic variation of Alternaria solani from a potato production region. Eur. J. Plant Pathol., 134: $847-858$. 


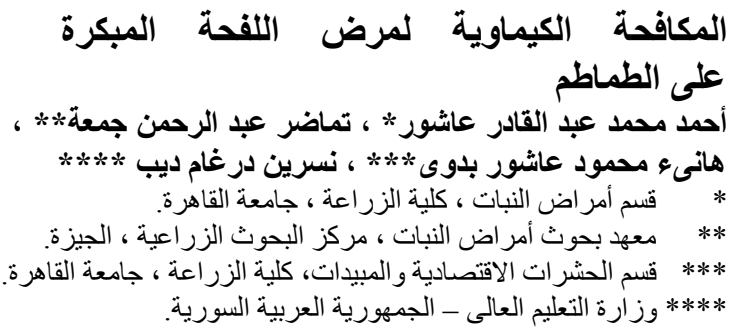

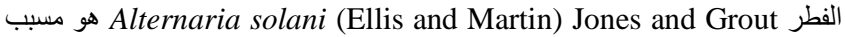

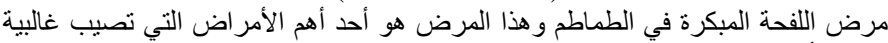

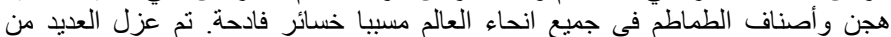

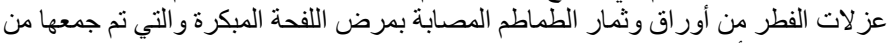

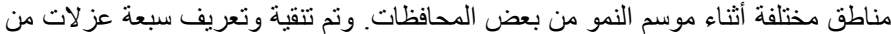

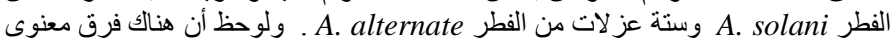

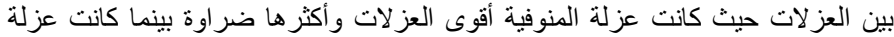

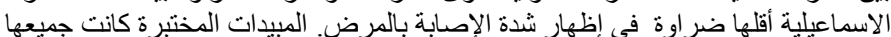

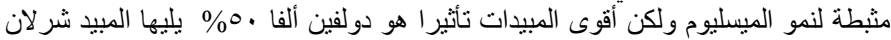

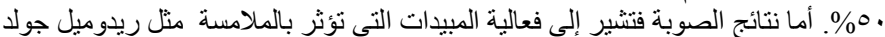

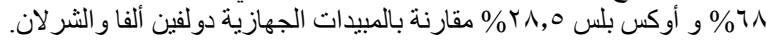

